DOI: 10.20472/IAC.2017.031.031

\title{
SUSANNA MENIS
}

Birkbeck London University, United Kingdom

\section{NON-TRADITIONAL STUDENTS AND CRITICAL PEDAGOGY: TRANSFORMATIVE PRACTICE AND THE TEACHING OF CRIMINAL LAW}

\begin{abstract}
:
This article explores the practical implication of adopting critical pedagogy, and more specifically critical legal pedagogy, in the teaching of non-traditional students in HE context. It is based on the teaching of criminal law at Birkbeck School of Law, addressing learning tasks which have been designed to enhance students' learning experience. The proposition put forward in this article suggests that exactly because many of the non-traditional, mature students do not intend to pursue an ad hoc legal profession, the teaching approach should be geared towards widening the social context of learning and the acquisition of transferable skills, but mainly towards fostering students' social 'transformation'.
\end{abstract}

\section{Keywords:}

non-traditional students; widening participation; student-centred-approach; threshold concepts; critical (legal) pedagogy. 